\title{
KOMUNIKASI EFEKTIF ANTARA ORANGTUA DENGAN ANAK BERKEBUTUHAN KHUSUS TUNAGRAHITA DALAM MEMBIASAKAN BERIBADAH DI SLB NEGERI BREBES
}

\author{
Almardliyatul Wardatun Nisa A ${ }^{1}$, M. Nurul Yamin ${ }^{2}$, Muhammad Samsudin ${ }^{3}$ \\ 1,2,3 Universitas Muhammadiyah Yogyakarta, Bantul, Yogyakarta, Indonesia \\ Ialmardliyatul@gmail.com, ${ }^{2}$ moehyamien@umy.ac.id, ${ }^{3}$ Muhsam29@gmail.com
}

\begin{abstract}
ABSTRAK
Manusia tidak dapat dilepaskan dari komunikasi, baik komunikasi interpersonal, komunikasi intrapersonal, dalam kehidupan sehari-hari untuk mencapai komunikasi efektif antara manusia satu dengan manusia yang lain. Komunikasi efektif adalah komunikasi yang antar individunya memahami satu tujuan bersama. Komunikasi yang baik antara orangtua dengan anak akan menimbulkan dampak yang baik pula pada keluarga hanya saja tidak semua keluarga mampu berkomunikasi dengan baik diantara anggota keluarga. Terlebih keluarga yang memiliki anak berkebutuhan khusus tunagrahita. Penerimaan ini akan berdampak pada komunikasi efektif yang berlangsung antara orangtua dengan anak berkebutuhan khusus tunagrahita di SLB Negeri Brebes. Metode penelitian ini adalah penelitian deskriptif kualitatif. Karakteristik subyek dalam penelitian ini sebanyak empat orang dengan empat orangtua memiliki anak gangguan khusus tunagrahita ringan. Teknik pengumpulan data dengan cara wawancara sebagai metode utama dan metode observasi sebagai metode pendukung. Hasil penelitian menunjukan bahwa ke empat keluarga sudah melakanakan komunikasi efektif antara orangtua dengan anak berkebutuhan khusus tunagrahita dalam membiasakan beribadah. Selain itu, faktor pendukung dari komunikasi efektif dalam mebiasakan beribadah menggunakan media audio visual. Sedangkan faktor penghambat dari komunikasi efektif antara orangtua dengan anak tunagrahita pola pikir yang lambat, emosi yang tidak stabil pada anak karena memiliki berkebutuhan khusus tunagrahita.
\end{abstract}

Kata Kunci: komunikasi efektif, anak berkebutuhan khusus tunagrahita, ibadah

\section{EFFECTIVE COMMUNICATION BETWEEN PARENTS AND CHILDREN WITH MENTAL RETARDATION IN GETTING USED TO WORSHIP AT SLB NEGERI BREBES}

\begin{abstract}
Humans cannot be separated from daily communication to achieve effective communication between one human and another. Effective communication is the communication between individuals understanding a common goal. Good communication between parents and children will have a good impact on the family; unfortunately, not all family have good communication among the members, particularly the families with mental retardated children. This condition will affect the effective communication between parents and the children. Therefore, this study aimed to describe effective communication between parents and mental retardated children at SLB Negeri Brebes as well as to elaborate on the supporting and inhibiting factors inside. The method of this research was qualitative descriptive. The characteristics of the subjects were four families with four parents having children with mild mental retardation. Data were collected through interviews, as the main method, and observation, as a supporting method. The results showed that the communication between parents and their mental detardated children from the four families were effective in getting used to worship. This was supported by the use of audio-visual media. Meanwhile, the inhibiting factors of effective communication between parents and children with mental retardation were slow thinking patterns and emotional instability in children since they had mental retardation.
\end{abstract}

Keywords: effective communication, children with mental retardation, worship

\begin{tabular}{|c|c|c|}
\hline Submitted & Accepted & Published \\
\hline 04 Agustus 2021 & 05 Oktober 2021 & 27 November 2021 \\
\hline
\end{tabular}

\begin{tabular}{|l|c|c|}
\hline Citation & $:$ & $\begin{array}{r}\text { Nisa A, A.W., Yamin, M. N., \& Samsudin, M. (2021). Komunikasi Efektif Antara Orangtua Dengan Anak Berkebutuhan } \\
\text { Khusus Tunagrahita Dalam Membiasakan Beribadah Di SLB Negeri Brebes. Jurnal PAJAR (Pendidikan dan } \\
\text { Pengajaran), 5(6), 1732-1739. DOI : http://dx.doi.org/10.33578/pjr.v5i6.8493. }\end{array}$ \\
\hline
\end{tabular}

\section{PENDAHULUAN}

Komunikasi merupakan bagian yang tidak dapat dipisahkan dalam kehidupan sehari-hari manusia. Melalui komunikasi manusia bisa bertukar informasi, berbagi, dan mengembangkan diri. Komunikasi adalah suatu proses penyimpanan informasi (pesan, ide, gagasan) dari pihak satu ke pihak lain. (Ngalimun, 2017) Komunikasi yang dilakukan setiap hari sesekali 
menghadapi suatu hambatan dalam penyampaian suatu informasi, pengiriman pesan sehingga pemahaman pesan hingga terhadap lawan bicara hingga terciptanya komunikasi efektif, komunikasi efektif sendiri diartikan dengan komunikasi yang mampu menciptakan suatu perubahan sikap ataupun perubahan perilaku serta perubahan opini pada orang yang terlibat komunikasi.

Ibadah sendiri adalah sesuatu yang dikerjakan oleh umat manusia agar lebih dekat dengan tuhannya, dalam beribadah orang tua harus menanamkannya sejak dini, orang tua mengajak anak mengenal siapa tuhannya dan kewajiban bertuhan. Maka dari itu, sangat diharuskan bagi orang tua untuk menanamkan nilai-nilai Islam pada anak, Kewajiban ajaran Islam yang ditanamkan pada anak seperti : aqidah, akhlak, dan ibadah. Pada kehidupan dalam keluarga saat ini orang tua yang memiliki tanggung jawab penuh untuk mendidik anaknya namun pada kenyataannya malah dilimpahkan pada pendidik seperti guru , karena keharusannya dalam melengkapi kebutuhan dan juga minimnya ilmu pengetahuan, pendidikan dari orang tua.

Keluarga adalah bagian sosial terkecil yang memberikan fondasi primer bagi perkembangan anak, sedangkan lingkungan sekitar ikut berperan dalam perkembangan anak. Hal ini yang menentukan baik-buruknya pertumbuhan kepribadian anak, bisa dilihat dari baik strukturnya keluarga dan masyarakat sekitar. Keluarga memiliki fungsi penting dalam perkembangan anak, seperti dalam hal dukungan, bimbingan dan pengarahan yang diberikan keluarga kepada anak. Fungsi ini tidak dapat berjalan dengan baik tanpa adanya komunikasi antara keluarga yaitu orang tua terhadap anak yang baik dan tepat. Apabila komunikasi yang dilakukan oleh orang tua tidak harmonis atau tidak tepat maka akan muncul konflik antara orang tua dengan anak, begitu juga sebaliknya dan terjadi komunikasi yang tidak efektif. Komunikasi keluarga yang baik adalah aspek penting dan memiliki pengaruh besar untuk kehidupan anak. Karakter dan sikap yang melekat pada anak adalah cerminan dari komunikasi efektif yang terjalin antara orang tua dengan anaknya.
Peneliti mengambil fokus anak berkebutuhan khusus yang mengalami gangguan fisik tunagrahita atau yang biasa disebut dengan keterbelakngan mental, menurut buku pendidikan dan bimbingan anak berkebutuhan khusus karya Jati Rinarki (2018), tunagrahita adalah suatu kondisi anak yang kecerdasannya jauh dibawah rata-rata dan ditandai oleh keterbatasan intigensi dan ketidakcakapan dalam komunikasi sosial, ketidak mampuan tunagrahita dalam menangkap pesan karena keterbatasan yang dimilikinya seperti tidak bisa atau melambannya proses pesan di otak dan gangguan neurologi pervasif ini terjadi pada aspek neurobiologis otak yang mempengaruhi proses berkembangnya anak. Akibat gangguan ini anak akan tidak dapat secara otomatis belajar untuk melakukan interaksi dan berkomunikasi dengan lingkungan sekitarnya.

Orangtua harus siap dengan berbagai masalah yang akan muncul pada pribadi anak tunagrahita, seperti komunikasi, aspek sosial, kurangnya berinteraksi dengan lingkungan, sulit memahami perintah, gerak-gerik anggota tubuh yang sulit terarah, tidak bisa merasakan empati dan hal sebaliknya. Hal-hal seperti itulah yang harus lebih diperhatikan oleh orang tua anak berkebutuhan khusus tunagrahita. Senada dengan penelitian Assyifa Nur Pratiwi (2021) Pola Komunikasi Terapis dengan ABK menyatakan dalam hal komunikasi, anak berkebutuhan khusus tunagrahita akan lamban dalam hal memahami, namun anak dengan gangguan tunagrahita mampu menunjukan kemampuan yang terkadang orang lain tidak bisa melakukannya, serta dalam hal lain anak tunagrahita akan lebih sulit menuruti suatu perintah atau intruksi dan tidak bisa melakukan hal-hal yang dirasa mudah bagi anak normal pada umumnya.

Pada proses beribadah anak tunagrahita, orang tua tentunya harus lebih ekstra dalam mengajarkannya, karena bukan tidak gampang mengajarkan ibadah kepada anak yang berkebutuhan khusus tunagrahita, mereka akan penuh perlawanan, dan lamban dalam menangkap serta merekam sesuatu yang diajarkan. Penelitian terdahulu Rifka (2020) yang berjudul Metode Pembelajaran Agama bagi ABK juga menyatakan hal serupa, dalam pergerakannya orangtua harus dengan sabar membiasakan ibadah seperti sholat, 
puasa dan mengaji, karena secara memorial anak berkebutuhan tunagrahita akan lama menangkap namun sangat baik dalam hal mengingat. Mengajarkan ibadah kepada autis bukanlah hal yang gampang orang tua pun harus telaten mengjarinya, satu demi satu gerakan sholat, dan membimbing dengan penuh kasih sayang untuk belajar beribadah.

Secara teori tunagrahita adalah suatu kondisi anak yang kecerdasannya jauh di bawah rata-rata dan ditandai oleh keterbatasan inteligensi dan ketidak cakapan dalam komunikasi sosial, dalam kondisi inilah pad akenyataannya anak tunagrhita sulit untuk diajari sholat namun di SLB Negeri Brebes, anak tunaghrahita menjalakan sholat walaupun hanya menjalankan shalat dzuhur yang diwajibkan di sekolah. Berdasarkan fakta inilah mengapa penulis mengambil judul Komunikasi efektif antara orangtua dan anak berkebutuhan khusus tunagrahita dalam membiasakan beribadah di SLB Negeri Brebes, karena di SLB Negeri Brebes para orangtua masih belum mampu berkomunikasi dengan baik dengan anak-anak yang berkebutuhan khusus tunagrahita dalam membiasakn beribadah. Sampel dalam penelitian ini adalah 10 keluarga yang mempunyai anak berkebutuhan khusus tunagrahita, bisa dikatakan tingkat kesadaran mereka masih bisa dikatakan sangat rendah sekitar $40 \%$ penyebabnya adalah kesabaran orangtua yang kurang dalam menghadapi anaknya, seringkali dalam proses ibadah orangtua menyerahkan kembali pada apa yang didapat dan apa yang anak serap. Dalam pembiasaan beribadah pada anak tunagrahita harus dengan komunikasi yang ekstra agar komunikasi berjalan dengan efektif dan diterima baik oleh anak berkebutuhan khusus tunagrahita, kasus kurangnya orang tua memberikan perhatian pada anak tentang penanaman ibadah terjadi di SLB N 1 Brebes, hampir dari semua orangtua menyerahkan segalanya kepada guru atau pendidik anak berkebutuhan khusus tunagrahita.

Manfaat dari penelitian ini adalah memberikan pemahaman kepada Orangtua dan anak dalam proses komunikasi sehari-hari di sekolah ataupun di rumah serta memberikan kontribusi dalam pengembangan ilmu komunikasi, terkhusus untuk komunikasi efektif orang tua dengan anak berkebutuhan khusus dalam membiasakan ibadah, karena memiliki kasus dan keterkaitan yang erat pada komunikasi efektif ini dalam kehidupan sehari-hari dalam pembiasaan beribadah, diharapkan menjadi stimulus bagi penelitian selanjutnya sehingga proses pengkajian terus berlangsung dan mendapatkan hasil yang maksimal. Tujuan dari penelitian ini adalah menjelaskan tentang komunikasi efektif antara orangtua dengan anak berkebutuhan khusus dalam membiasakan beribadah, serta mengetahui faktor apa saja yang mempengaruhi komunikasi efektif antara orangtua dengan anak berkebutuhan khusus dalam membiasakan beribadah.

\section{KAJIAN TEORETIS}

\section{Komunikasi Efektif}

Komunikasi efektif di sini adalah komunikasi yang di dalamnya komunikator dan komunikan sama-sama memiliki persepsi dan tujuan yang sama tentang suatu pesan. Menurut devito komunikator efektif diciptakan, bukan dilahirkan. (Devito, 2011) Bagaimanapun tingkat keterampilannya, kita dapat meningkatkan efektifitas dengan menerapkan gagasan secara aktif. Komunikasi yang efektif disebabkan adanya pengertian, dapat menyebabkan kesenangan, mempengaruhi sikap, menjalin keberlangsungan sosial yang baik, dan harapannya terciptanya suatu perilaku.

\section{Tujuan Komunikasi Efektif}

Menurut Devito ada beberapa tujuan dalam komunikasi, tujuan ini tidak perlu diungkapkan secara terang-terangan, dan juga tidak perlu menyepakati tujuan komunikasi mereka (Devito, 2011):

a. Menemukan atau penemuan diri, persepsi diri sebagian besar dihasilkan dari apa yang anda telah pelajari tentang diri sendiri dan orang lain selama berkomunikasi.

b. Untuk berhubungan, berhubungan dengan orang lain membina dan memelihara hubungan dengan orang lain.

c. Pemecahan masalah hubungan antar manusia.

\section{Ciri-Ciri Komunikasi Efektif}

Dalam buku Komunikasi Antarpribadi, Alo Liliweri mengutip pendapat Joseph A.Devito 
mengenai ciri komunikasi antar pribadi yang efektif, yaitu:

a. Keterbukaan (openness) : Kemauan menanggapi dengan senang hati informasi yang diterima di dalam menghadapi hubungan antarpribadi. Kualitas keterbukaan mengacu pada tiga aspek dari komunikasi interpersonal.

b. Empati (empathy) : kemampuan seseorang untuk mengetahui apa yang sedang dialami orang lain pada suatu saat tertentu, dari sudut pandang orang lain itu, melalui kacamata orang lain itu.

c. Dukungan (supportiveness) : Situasi yang terbuka untuk mendukung komunikasi berlangsung efektif. Individu memperlihatkan sikap mendukung dengan bersikap deskriptif bukan evaluatif, spontan bukan strategi.

d. Rasa Positif (positiveness) Seseorang harus memiliki perasaan positif terhadap dirinya, mendorong orang lain lebih aktif berpartisipasi, dan menciptakan situasi komunikasi kondusif untuk interaksi yang efektif.

Kesetaraan (equality) Komunikasi antarpribadi akan lebih efektif bila suasananya setara. Artinya, ada pengakuan secara diam-diam bahwa kedua belah pihak menghargai, berguna, dan mempunyai sesuatu yang penting untuk disumbangkan.

\section{METODE PENELITIAN}

Penelitian ini akan dilakukan dengan cara pendekatan kualitatif. (Ismail, 2015) Serta Studi kasus dengan instrumen tunggal (single instrumental case study) adalah studi kasus yang terfokus pada satu isu atau pusat perhatian saja yaitu anak berkebutuhan khusus tunagrahita diSLB Negeri Brebes, dan hanya digunakan satu kasus yang terbatas yaitu komunikasi efektif dalam membiasakan beribadah. Hal ini karena tema penelitian membutuhkan analisis mendalam berupa observasi masalah, terhadap suatu fakta yang ada maupun fenomena yang akan di selidiki dalam studi kasus.

Lokasi penelitian menetapkan di SLB Negeri Brebes Jawa Tengah, dengan 10 keluarga yang diobservasi dan 4 keluarga yang diambil untuk penelitian lanjutan. 4 keluarga ini mempunyai latar belakang orangtua yang beragam, sarana dan prasarana yang lengkap serta di sekolah ini belum pernah diadakan penelitian mengenai komunikasi efektif antara orangtua dengan anak berkebutuhan khusus tunagrahita dalam membiasakan beribadah, Penelitian ini menggunakan tehnik pengumpulan data berupa, Pengamatan, Wawancara Mendalam.

\section{HASIL DAN PEMBAHASAN}

Proses dan langkah-langkah dalam komunikasi efektif:

1. Harapan melakukan komunikasi. Harapan yang dilakukan setiap keluarga berbeda-beda, keluarga 1 mengajak berkomunikasi meskipun anak tidak selalu memahami apa yang dibicarakan orangtua, maka dari itu orangtua selalu mengulang pembicaraan agar anak memahaminya. Misalnya saat orang tua menanyakan dan mengajak anak untuk sholat, anak masih lama untuk berfikir dan mencerna apa yang orangtua bicarakan, sehingga orangtua mengulang petanyaan yang sama dengan gerakan, barulah anak meberikan respon kepada orangtua dengan beratanya kembali, keluarga 2 memberikan pengulangan dalam berkomunikasi dengan anaknya yang berkebutuhan khusus tunagrahita, seperti bertanya tentang keingian anak makan apa hari ini, minta mandi sendiri, pakai baju sendiri sampai menyuruh sholat, dalam segala hal keseharian orang tua selalu melalukan komunikasi dengan anaknya supaya anak terbiasa untuk berfikir dan selalu melakukan interaksi.

2. Encoding oleh komunikator. Setelah adanya harapan melakukan komunikasi kemudian orangtua sebagai komunikator mempersiapkan apa saja yang akan disampaikan kepada anak sebagi komunikannya. Encoding dalam keluarga \#1, \#2, \#3,\#4 umumnya sama namun ada beberapa kendala yang hadir karena dari anak berkebutuhan khusus tunagrahita. anak tunagrahita ringan seperti keluarga 1 dan 3 yang masih bisa diajak komunikasi dengan menggunakan bahasa keseharian manusia normal lainnya namun sedikit lebih halus dalam penyampaiannya, karena bagi mereka orang yang berbicara dengan nada tinggi atau 
lebih sering dikenal membentak. Anak pada keluarga 2 dan 4 akan cenderung lebih gampang merasakan sedih bahkan sampai menangis, orangtua sedikit sulit dalam menyampaikan gagasan kepada anak dikarenakan umur anak yang masih kecil dan anak mempunyai kebutuhan khusus tunagrahita, disitulah hambatan-hambatan yang sering terjadi dalam melaksanakan komunikasi, menyampaikan pesannya selain melalui kata-kata yaitu melalui media lain seperti handphone untuk membantu orangtua untuk merekam didaya ingat anak tentang hafalan Al-Qur'an, namun tidak jarang enconding terdapat hambatan penekanan secara berulang yang dilakukan oleh orangtua kepada anak, setiap diajarkan shalat dia masih seenaknya sendiri, tingkat emosianal dan tubuh yang tidak sempurna membuat orangtua kesulitan dalam menyampaikan pesan terhadap anak keluarga.

3. Pengiriman Pesan. Pada keluarga \#1, \#2, \#3, \#4 orangtua sebagai pengirim pesan sedikit mendapatkan hambatan karena anak yang masih semaunya sendiri, dalam wawancara mendalam bersama orangtua dan pengamatan keseharian, anak jika dipaksa anak akan merasa tidak nyaman dan terjadi pergejolakan emosional, tenaga ekstra dalam penyampaian komunikasi dengan anak, seperti yang sudah dijelaskan pada point sebelumnya anak yanng tergolong masih kecil, orangtua dalam mengirimkan pesan kepada anak harus disertai gerakan karena daya ingat yang masih terus berproses untuk mengingat. Hal ini menghasilkan bahwa setiap pengiriman pesan tidak hanya melalui kata-kata atau lisan saja tapi bisa melalui gerah tubuh untuk menunjang pengiriman pesan terhadap anak terjadi dengan baik.

4. Terkirimnya pesan. Perbedaan setiap anak pada ke 4 keluarga akan berbeda-beda tergantung IQ yang dipunyainya, IQ itu juga yang menjadi salah satu faktor penghambat terjadinya komunikasi efektif antara orangtua dengan anak berkebutuhan khusus tunagrahita, pola pikir yang lamban membuat komunikator tidak jarang mengulang pernyataan-pernyataan yang ingin disampaikan supaya pesan tersampaikan dengan baik kepada komunikan (anak tunagrahita). Dtermasuk yang berjalan dengan baik komunikasi efektif antara orangtua dengan anak berkebutuhan khusus tunagrahita, setiap orangtua menyuruh anak shalat, anak merespon dengan baik, karena sejak kecil sudah terbiasa diajak Bapaknya ke Masjid menjadikannya terbiasa dengan shalat, saat orangtua mengajarinya bacaan shalat, bacaan wudhu tidaklah sulit karena anak sendiri sudah sering mendengarkannya di Masjid. Lain halnya dengan keluarga yang sulit bekomunikasi untuk membiasakan beribadah dengan baik oleh orangtua kepada anak, karena dari segi postur tubuh yang sulit berinteraksi, dan pengecilan otak sehingga membuat anak sulit dalam berkomunikasi. Dalam membiasakan beribadah pengajaran orangtua selalu dilakukan dengan tindakan, seperti membiasakan shalat yaitu orangtua harus mengajaran secara lisan dan gerak agar anak mampu memahaminya

5. Decoding oleh komunikan: ke 4 keluarga dalam melakukan Decoding ini terjalin dengan baik, karena anak berkebutuhan tunagrahita semua panca inderanya masih tergolong normal, hanya saja daya tangkap mereka yang dibawah rata-rata dan membuat respon dari mereka lambat. Keluarga \#1 anak mempunyai keinginan untuk melakukan shalat karena oarangtua yang membiasakan shalat, keluarga \#2 anak selalu diajarkan dan dibawa ke masjid sedari kecil, dirumah juga diajarkan shalat, keluarga \#3 orangtua melakukan komunikasi dirumah dalam mengajarkan shalat cukup sederhana, sedari kecil anak diceritakan hal-hal kewajiban shalat dan perkara jika ditinggalkannya, meskipun begitu orangtua tidak terlalu memaksakan jika anak tidak mau shalat karena jika dipaksa bisa membuat anak marah, perimaan perintah oleh anak melalui mata dan pendengaran secara berulang. Sikap yang dihasilkan anak berkebutuhan khusus masing masing anak akan berbeda tergantung dengan Decoding yang dilakukan oleh orangtuanya, keluarga \#4 disaat orangtua menyuruh sholat respon langsung dari anak 
bisa langsung mau shalat atau malah menolak perintah tergantung mood anak.

6. Umpan Balik : Umpan balik ini terjadi apabila komunikasi antara komunikan dan komuikator berjalan dengan baik, saling mengerti, dan saling memahami satu sama lain, dalam komunikasi antara orangtua dengan anak di rumah umpan balik antara masing-masing keluarga berbeda, hampir semua keluarga berjalan dengan baik namun dengan kendalanya masing-masing seperti, emosional anak yang meledak saat tidak ingin diajak berkomunikasi,umpan balik yang terjadi lambat karena proses berpikir anak.

\section{Ciri-Ciri Komunikasi Efektif}

Dari ke 4 keluarga mempunyai ciri-ciri komunikasi efektif yang relatif sama. Menurut Joseph A.Devito mengenai ciri komunikasi antar pribadi yang efektif, yaitu:

1. Keterbukaan (openness) : Keterbukaan ini terjadi ketika komunikasi terjalin secara efektif dengan menanggapi hubungan dengan baik, dalam pembiasaan beribadah di rumah orangtua mengajarkan secara terbuka tidak mengekang, dengan membiaskan anak melihat dan mengamati orang shalat di Masjid membuat anak mempunyai kemauan untuk melaksakan dan mencobanya sendiri dirumah, adanya kemauan anak untuk menjalankan shalat itu artinya muncul sebuah kemauan muncul juga adanya keterbukaan, meski tidak secara langsung dan membutuhkan waktu lama, Sejatinya keterbukaan hadir bukan hanya dari anak saja namun juga hadir dari orangtua, orangtua yang kurang mengerti dengan kata-kata anak, setelah dijelaskan oleh anak barulah orangtua mengerti, dari ciri-ciri keterbukaan menghasilkan pengakuan untuk melaksakan shalat serta pengakuan untuk pengoreksian dalam membaca Al-Qur'an.

2. Empati (empathy) : Dukungan orangtua selalu tercurahkan kepada anaknya, terlebih orangtua dari anak berkebutuhan khususu tunagrahita karena mereka menginginkan walaupun anak dengan kekurangan harus dekat dengan Allah, Allah yang menciptakan, Allah yang memberikan dengan keadaan seperti itu baik orangtua dan anak harus tetap merasa bersyukur

3. Dukungan (supportiveness) :Dukungan orangtua selalu tercurahkan kepada anaknya, terlebih orangtua dari anak berkebutuhan khususu tunagrahita karena mereka menginginkan walaupun anak dengan kekurangan harus dekat dengan Allah, Allah yang menciptakan, Allah yang memberikan dengan keadaan seperti itu baik orangtua dan anak harus tetap merasa bersyukur. Berbagai dukungan yang dilakukan oleh keluarga \#1 terutama dalam hal beribadah, orangtua mendukung anaknya untuk rajin beribadah dengan cara membawanya ke Masjid selain untuk membiasakan beribadah kegiatan ini untuk mebiasakan anak-anak untuk bersosialisasi dengan masyrakat.

4. Rasa Positif (positiveness) : Dalam berkomunikasi agar efektif adalah adanya rasa positif, perasaan positif terhadap dirinya sendiri dan mendorong oranglain, yang berperan disini adalah orangtua, mereka harus memberikan rasa postif kepada anak agar anak dapat aktif bertisipasi dalam komunikasi. Rasa positive selalu ditanamkan oleh orangtua untuk menerima keadaan anaknya yang mempunyai kebutuhan khusus tunagrahita, karena bagi mereka bagaimanapun anak itu adalah titipan tuhan yang harus dijaga dan tetap didekatkan kepada Allah.

5. Kesetaraan (equality): Seperti yang sudah dijabarkan dari penjelasan diatas setaraan ini terjadi, namun dengan waktu yang tidak cepat, dan pengulangan yang dilakukan beberpa kali. Kesetaraan ini terjadi apabila kedua belah pihak saling setuju akan adanya komunikasi. Dalam setiap keluarga yang mempunyai cara sendiri untuk mencapai kesetaraan.

Dari hasil penelitian keluarga \#1, \#2, \#3, \#4 Faktor yang mempengaruhi komunikasi efektif orangtua dengan anak berkebutuhan khusus tunagrahita dalam membiasakan beribadah adalah:

1. Emosi anak menurut Jati Rinarki emosiaonalnya adalah anak tunagrahita memiliki ketidakmampuan untuk memahami aturan sosial dan keluarga, sekolah serta 
masyarakat. Dari hasil penelitian 4 keluarga anak berkebutuhan khusus tunagrahita emosi anak sangat mempengaruhi komunikasi orangtua dengan anak, komunikasi akan efektif apabila anak dalam keadaan tenang bukan dalam keadaan marah.

2. Media yang digunakan, masih menurut Jati Rinarki media yang digunakan dalam mengajarkan anak berkebutuhan khusus sangatlah membantu dalam proses komunikasi, media ini dapat menghantarkan pesan komunikasi yang akan disampaikan kepada anak berkebutuhan khusus dalam proses tercapainya tujuan komunikasi. Media yang digunakan yaitu seperti menggunakan media audio ataupun visual untuk mendukung komunikasi efektif dalam pembiasaan anak dalam melaksanakan ibadah, seperti yang dilakukan oleh keluarga \#1 dan keluarga \#3.

Kemampuan berpikir anak, tunagrahita adalah suatu kondisi anak yang kecerdasannya jauh dibawah rata-rata dan ditandai oleh keterbatasan inteligensi dan ketidak cakapan dalam komunikasi sosial. Anak berkebutuhan khusus ini juga sering dikenal dengan istilah terbelakang mental karena keterbatasan kecerdasannya. Akibatnya anak berkebutuhan khusus tunagrahita ini sukar untuk mengikuti pendidikan disekolah biasa. (Jati Rinakri Atmaja, 2018) Kemampuan berfikir anak sangatlah mempengaruhi keberlangsungan komunikasi nantinya, anak berkebutuhan khusus tunagrahita yang biasa dikenal dengan IQ yang lemah atau dibawah rata-rata, kemampuan berfikir anak ini memicu adanya pengulangan informasi dari orangtua kepada anak untuk mencapai suatu pemahaman.

\section{SIMPULAN DAN REKOMENDASI}

Komunikasi yang dilakukan oleh 4 keluarga dari orangtua yang memiliki anak berkebutuhan khusus tunagrahita ringan menunjukan proses dalam komunikasi efektif serta klasifikasi komunikasi efektif yang berhasil walaupun dalam menjalankannya masingmasingnya dengan cara yang berbeda untuk mencapai komunikasi efektif, dan kendala yang dihadapi oleh masing-masing keluarga pun beda, terlihat komunikasi efektif yang baik terjadi pada keluarga \#1, dan \#3, keluarga \#2 dan \#4 menghadapi beberapa kendala karena faktorfaktor yang dimiliki oleh anak berkebutuhan khusus tunagrahita.

Faktor pendukung dalam mencapai komunikasi efektif antara orangtua dengan berkebutuhan khusus tunagrahita ringan adalah emosi anak yang sedang baik, adanya media audio seperti yang diterapkan oleh keluarga \#1, \#3 yang dibiasakan untuk mendengar suara adzan, dan Murotal via handphone, kemudian faktor pendukung yang lain adalah dari orangtua yang sabar dan telaten dalam memberikan pengajaran dan membiasakan beribadah kepada anak. Faktor penghambat dalam mencapai komunikasi efektif ini adalah emosi anak berkebutuhan khusus tunagrahita yang masih belum bisa terkontrol, pola pikir anak yang lamban. Orangtua denga anak berkebutuhan khusus tunagrahita ringan, berkomunikasi dengan cara memberikan penjelasan secara berulangulang dalam berkomunikasi dengan anak.

Orangtua yang memiliki anak berkebutuhan khusus tunagrahita untuk memberikan komunikasi yang baik kepada anak. Diharapkan bagi orangtua meskipun anak memiliki kekurangan dalam hal memahami, orangtua hendaknya memberikan pemahaman yang lebih mendalam dan berulangulang kepada anak serta memberikan hukuman ataupun ancaman ringan ketika anak tidak mau menjalankan ibadah. Bagi Masyarakat untuk tidak mengucilkan anak yang memiliki kebutuhan khusus tunagrahita dan menghargai keberadaan mereka, selain itu masyarakat disarankan untuk memberikan ruang hidup yang baik dan meperlakukan anak berkebutuhan khusus tunagrahita sama seperti anak normal pada umumnya.

\section{DAFTAR PUSTAKA}

Devito, J. A. (2011). Komunikasi Antar Manusia. Tangerang: Karisma Publishing Group.

Ismail, N. (2015). Metodelogi Penelitian Untuk Studi Islam: Paduan Praktis Dan Diskusi Isu. Yogyakarta: Universitas Muhammadiyah Yogyakarta.

Jati, R. A. M. (2018). Pendidikan Dan Bimbingan Anak Berkebutuhan Khusus. Bandung: PT Remaja Rosdakarya. 
Jurnal PAJAR (Pendidikan dan Pengajaran)

Volume 5 Nomor 6 November | ISSN Cetak : 2580 - 8435| ISSN Online : 2614 - 1337

DOI : http://dx.doi.org/10.33578/pjr.v5i6.8493

Ngalimun. (2017). Ilmu Komunikasi Sebuah Pengantar Praktis. Yogyakarta: Pt Pustaka Baru Pers.

Pratiwi, A., \& Syifa, N. (2021). Pola Komunikasi Terapis Dalam Terapi Perilaku Anak Penyandang Autis Di Lembaga $U$ \& Me Care Palembang. Diss. Fakultas Ilmu Sosial Dan Ilmu Politik.

Apriandani, F. M. (2019). Penerapan Strategi Video Learning Dalam Pembelajaran Pai Bagi Anak Tunagrahita Di Sekolah Luar Biasa Rindang Kasih Secang Magelang. Diss. Skripsi, Universitas Muhammadiyah Magelang. 